\title{
The Bible as a Resource for Teaching Cataloguing and Classification
}

\author{
Vincent E. Unegbu ${ }^{1, *} \&$ Uloma D. Onuoha ${ }^{1}$ \\ ${ }^{1}$ Information Resources Management, Babcock University, Ilishan Remo, Nigeria \\ *Corresponding author: Information Resources Management, Babcock University, Ilishan Remo, PMB 21244, Ikeja, \\ Lagos, Nigeria Tel: 234-813-158-1233 E-mail: vinunegbu@yahoo.com; ud_onu@yahoo.com
}

Received: January 23, 2013 Accepted: April 8, $2013 \quad$ Online Published: April 29, 2013

doi:10.5430/jct.v2n1p101 URL: http://dx.doi.org/10.5430/jct.v2n1p101

\begin{abstract}
The Bible is an important book that represents all courses that human beings engage in. Many professions use it as a textbook for their course, as are listed in this write up. In spite of the rich source of information embedded in it, library and information professions are yet to tap into it. The first two chapters of the Bible are a very good source of the course Cataloguing and Classification (Cat. \& Class.). The aim of this paper is to expose the rich curriculum content of Cat. \& Class. in this book of Genesis and to use it as an example of what the Bible could offer in the teaching of Cat. \& Class. and other library and information courses. It appeals to Library and Information Science professionals to use the Bible as a textbook in the course, in addition to other lessons learnt from the book of Genesis.
\end{abstract}

Keywords: Bible; cataloguing; classification; librarianship

\section{Introduction}

Cataloguing and classification (Cat. \& Class.) are the basics and the core of librarianship. Broadly stated, cataloguing and classification are the roots of library and information science without which the profession would have no foundation. There would be no information organization without Cat. \& Class. Records management, librarianship, archives management, museum management, and even secretarial studies use Cat. \& Class. to organize their documents/acquisitions. God was the first cataloguer and the first classifier. In other words, God is a librarian, an information scientist.

Currently, the teaching of cataloguing and classification is being threatened in many library schools as Spillane (1999) described a trend where some library school either eliminate courses devoted to Cat. \& Class. or replace them with courses bearing the words "information" and "organization" in their titles. Tsiang (2006) also affirmed that the controversy has intensified so much that the issue now is on outsourcing of cataloguing and classification section of the library. The current situation, no doubt, threatens the transfer of knowledge of the principles of Cat. \& Class. which may likely go into extinction if the situation is not remedied.

\section{Objective of the Study}

The aim of this paper is to show that Cat. \& Class. is one of the earliest jobs provided by God. Using rich examples taken from one book and from two chapters out of the 66 books of the Bible, the paper brings to the notice of library and information scientists, the origin of Cat. \& Class.

\section{The Bible as a Study Guide}

In many courses taught in schools and universities, the Bible is used as a textbook (at least some portions of the Bible). Apart from Christian Religion whose main textbook is the Bible, there are a range of courses where the Bible is used as a complimentary textbook, if not as a main textbook. There is Bible as Literature (a course in Languages and Literary Analysis). Bible is used as a textbook in Ethics and Morals. Bible is used in teaching Law, in fact, a credit pass in religion is a requirement for doing Law. Bible is used in the teaching of Philosophy. It is a text in the teaching of Government, Civics and Ethics. It is used in teaching Benevolence and Philanthropy. It is used in 
teaching Economics and Commerce ("You must have accurate and honest weights and measures, so that you may live long in the land the LORD your God is giving you" (Deuteronomy 25:15); use accurate scales and accurate ephah, (Ezekiel 45:10); use perfect and just measure, (Leviticus 19:36)). In the Seventh-day Adventist Schools system, the Bible is used to set values and to test the teachers' values' compliance in teaching. In fact, the Bible's obvious presence is expected in every curriculum and course outline. Since all these professions have Bible teachings embedded in their courses, why should the Bible not be part of Library and Information Science textbook? Why should it be missing in cataloguing and classification? The book of Genesis chapter one illustrates how Cat. \& Class. can be used to bring order into chaos as shown in the story of creation.

\section{Cataloguing and Classification in Genesis Chapters $1 \& 2$}

The book of Genesis chapter one verse one summarizes the creation story. It is the topical statement of the whole chapter and of the creation. Verse two describes how the world was before God stepped in. Gen.1: 2 says that "the earth was without form, void; and darkness was upon the face of the deep. And the Spirit of God moved upon the face of the waters". Two things were obviously present: darkness and waters. The earth was "without form" and "void" and there was "darkness" and "waters". Imagine how it was! Everything clustered together, everything was scattered, no formality, no purpose, no order. God visualized this state of confusion and stepped in. God spoke light into existence. "Let there be light: and there was light" and He "divided the light from the darkness" (Gen.1: 3, 4). That was the beginning of classification. God separated light from darkness, giving form to a condition that was without form. Separation is the first act of classification. After separation, a notation mark was assigned to the "light" and to the "darkness"; they were assigned the marks or symbols of 'DAY' and 'NIGHT'. Is this not what librarians do? After separating the materials (books, journals, videos, etc.) a notation symbol was attached to them for distinction. In Gen.1: 6, there was a subdivision. There was the "firmament" that divided waters from waters; Gen.1:7 reads "And God made the firmament, and divided the waters which were under the firmament from the waters which were above the firmament: and it was so". After this subdivision, a notation mark was allotted to the firmament, and that was HEAVEN (Gen.1:8). Then came a sub-subdivision of the waters; "the waters under the heaven" were gathered in one place to create space for dry LAND. This dry land was given a notation mark called EARTH. Separation, division, subdivision, and sub-subdivision continued throughout the two chapters of the book. The waters that gathered in the earth God called SEAS. In Gen.1:6, water was separated from waters, because water covered everywhere. Some "waters" went up and some remained below. The water below was further divided to create land. The water on land He called seas. Later, the water on earth was further divided (sub-subdivided) and given different names and enclave.

Chapter two verses nine to fourteen of Genesis was naming of the rivers by the Creator. There was a river with 4 tributaries named by God as Pison (Gen.2: 11), Gihon (Gen.2: 13), Hiddekel (Gen.2: 14a), and Euphrates (Gen.2: 14b). This is a clear division from the body of waters of Gen.1: 6, and its subdivision of Gen.1: 10. The rivers were differentiated from each other by name and by course - area of flow.

PISON: This covers the whole land of Havilah, where there is gold.

GIHON: This "compasseth the whole land of Ethiopia".

HIDDEKEL: This flows towards the east of Assyria.

EUPHRATES: No course of its flow was given. This is an example of library material where the cataloguer has to look for external sources before assigning a class number to the material.

This is a typical example of assigning class numbers to objects. Note that the rivers were differentiated from each other. Every classified material must be distinct from the other.

Just as Gen.1: 1 is the summary of the whole creation, Gen.1: 27 is the topical sentence, the summary of how man was created or formed. Genesis 2: 7 and 8 showed how man was especially made/formed "from the dust of the ground" and God "breathed into his nostrils the breath of life; and man became a living soul". Two reasons were given in this book why man was created. There may be other reasons that are not stated in these two chapters of the book of Genesis. Reason number one was for man to till the ground (take care of the garden). This is clear in Gen.2: 5,15 , where God said that "there was not a man to till the ground, and the LORD God took the man, and put him into the garden of Eden to dress it and to keep it". Reason number two was for man to "have dominion over the fish of the sea, and over the fowl of the air, and over the cattle, and over all the earth, and over every creeping thing that creepeth upon the earth" (Gen.1:26). Man is the overseer of God's creation. Man is the caretaker and not the landlord. Library and information scientists are the custodians and managers of information repository. Library and 
Information Scientists should have "dominion" over the classification, cataloguing, and retrieval of information. This assignment is the profession of librarians, information scientists, documentalists, curators and all those who are involved in information resources management.

Adam, the first human being formed by God, gave names to all animals created by God. So the names we call the animals - tiger, lion, sheep, goat, cattle, etc. were given by Adam. Is this classification? Yes, it is! Is it like assigning book or call number to materials? Yes, it is!

It seems there is confusion among librarians, or the former librarians, on the sequence to follow in cataloguing and classification. What sequence should be followed in cataloguing and classification? What activities should be performed first, cataloguing or classification? In this creation example of Cat. \& Class., which was done first? How have librarians been doing it? Or, what have librarians been teaching? God started by classifying - separating like terms. Then He assigns names to them. He went back to the separated (classified items) and further separated again (classification). He describes (cataloguing) the groups and assigns a name or a tag (classification mark or notation mark). He separates, assigns names, and separates again. Therefore, it is classification, cataloguing, and classification. How do librarians and information scientists do it today? Let us start by defining cataloguing and classification.

\section{DEFINITION OF CLASSIFICATION AND CATALOGUING}

Classification in library and information science is different from taxonomy, which is the study of classification and naming of organisms (Chacha.com, 2012). This study is more pronounced in biology where taxonomy is defined as "The systematic grouping of organisms into categories on the basis of evolutionary or structural relationships between them" (Farlex, 2012). A bit of this, though, was noticed in the book of Genesis under study.

Library classification is a

system of arrangement adopted by a library to enable patrons to find its materials quickly and easily. While cataloging provides information on the physical and topical nature of the book (or other item), classification, through assignment of a call number (consisting of class designation and author representation), locates the item in its library setting and, ideally, in the realm of knowledge. Arranging similar things in some order according to some principle unites and controls information from various sources (Encyclopedia Britannica, 2012: 1).

Classification is the process of dividing objects or concepts into logically hierarchical classes, subclasses and sub-subclasses based on the characteristics they have in common and those that distinguish them" (Reitz, 2004:145). Kumar (2008: 1) defined it as "a process of grouping" which "involves putting together like entities and separating unlike entities". The characteristics of entities are used as a basis for determining the similarities or otherwise. It is clear from these definitions that classification is grouping similar entities together determined by their characteristics and assigning a class to them. This phenomenon was observed in the book of Genesis as water animals were different from land animals, as cattle, sheep, goats were different from humans represented by Adam, who, it was observed that, "there was not found a help meet for him" (Gen.2: 20) which led to the taking of Adam's rib to make a woman (Gen.2: 18-25). Let us now look at cataloguing.

The general or all purpose dictionaries do not quite grasp what cataloguing is, so, it is always attached to catalogue. Catalogue is "a list of itemized display, as of titles, course offerings, or articles for exhibition or sale, usually including descriptive information or illustration" (Farlex, 2012: 1). Cataloguing is "to enter in a catalog, to make a catalog of" (Dictionary.com, 2012: 1). Reitz (2004: 122) says that cataloguing is "The process of creating entries for a catalog". She went on to list what constitute the entries as bibliographic description, subject analysis, assignment of classification notation, and all the activities involved in physically preparing the items for the shelf. Kumar and Kumar (1981: 3) defined cataloguing as "The process of preparing a catalogue which denotes the various processes involved in the preparation of entries and maintenance of a catalogue". Cataloguing is a means to an end, it is not the end. It is a process that leads to assigning a classification mark to an item through which the item may be easily identified and located. Cataloguing and classification, which comes first?

\section{Sequence of Cataloguing and Classification}

In librarianship, the two activities are given a collaborative name of cataloguing and classification as if an attempt is being made to shy away from hierarchical placement of the activities. May be the Bible, the book of Genesis, may solve the problem for librarians. The first thing done in the creation story is to "separate darkness from light", separate waters from waters. Separation is classification. After separation God named the separated bodies. This is 
done using the characteristics of the items. Dry land He called Earth and the waters He called Seas. After this the Seas were further divided and given different names again (Gen.2: 10 - 14). Different lights were created also named according to their assignment. In this pattern we see classification, cataloguing, and classification again. Librarians may after all be right, Cat. \& Class. go together but it is not wrong to say that classification comes before cataloguing. After all, librarians will catalogue what they have identified (separated).

\section{Conclusion}

Library and information science is one of the oldest professions because it started from creation. It is part of creation activities. The Bible should be a textbook for library and information science courses. This is the major reason why this paper is written. It is not only to show Cat. \& Class. in the Bible but to solicit that library and information science curricula should have courses that reflect biblical views of the profession. There are biblical examples to teach or buttress the ethics of library and information science. From Genesis chapters one and two alone, there are many lessons that could be learned to enhance the profession. Orderliness is said to be the first law of Heaven and this is very prominent in this creation chapter of the Bible. There is orderliness, no chaos. And this is what Cat. \& Class. is all about - systematic arrangement of ideas and objects.

\section{References}

Chacha.com (2012). What is the study of classification or naming organisms. Retrieved Aug 21, 2012 from www.chacha.com/question/what-is-the-study-of-classification-or-naming-organisms

Encyclopedia Britannica.com (2012). Library classification. Encyclopedia Brit, Facts Matter. Retrieved August 22, 2012 from http://www.britannica.com/EBchecked/topic/339461/library_classification

Farlex (2012). Cataloging. The Free Dictionary. Retrieved August 20, 2012 from www.thefreedictionary.com/cataloging

Farlex (2012). Classification. The Free Dictionary. Retrieved August 20, 2012 from www.thefreedictionary.com/cataloging

Kumar, K. (2008). Theory of Classification ( ${ }^{\text {th }}$ Revised ed.). New Delhi: Vikas Publishing House PVT Ltd.

Kumar, G., \& Kumar, K. (1981). Theory of Cataloguing ( $3^{\text {rd }}$ ed.). New Delhi: Vikas Publishing House PVT Ltd.

Osborn, A. (1941). The crisis in cataloging. Library Quarterly, 11(4), 393-411.

Reitz, J. M. (2004). Cataloguing. Dictionary for Library and Information Science. London: Libraries Unlimited.

Reitz, J. M. (2004). Classification. Dictionary for Library and Information Science. London: Libraries Unlimited.

Spillane, J. (1999). Comparison of Required Introductory Cataloging Courses, 1986 to 1998. Library Resources and Technical Services, 43(4), 223-230.

The Holy Bible, King James Version. (2000). The American Bible Society. Retrieved August 22, 2012 from www.bartleby.com/108/01/2.html The two chapters of Genesis 1 and 2 are from this version.

Tsiang, A. (2006). Outsourcing. Amy Tsiang: Cataloging Outsourcing---Practice and Thinking. Presented at CEAL Committee on Technical Processing Program, San Francisco, Retrieved April, 2006 from http://www.eastasianlib.org/ctp/cealctp06/CEAL2006-Cataloging_Outsourcing.htm

Younger, J. (1991). Total quality management: Can we move beyond the jargon? ALCTS Newsletter, 2(8).

Dictionary.com (2012). Cataloguing. Retrieved August 20, 2012 from www.dictionary.reference.com/browse/cataloguing

The Bible (NIV) (1984). Deuteronomy 25: 15, Leviticus 19: 36. Retrieved August 22, 2012 from www.bible.cc/deuteronomy/25-15.htm \& www.bible.cc/leviticus/19-36.htm 